\title{
A bacterial environmental sensor that functions as a protein kinase and stimulates transcriptional activation
}

\author{
Michele M. Igo, Alexander J. Ninfa, and Thomas J. Silhavy \\ Department of Biology, Princeton University, Princeton, New Jersey, 08544 USA
}

\begin{abstract}
Transcription of the genes that encode the major outer membrane porin proteins OmpF and OmpC of Escherichia coli is regulated in response to changes in medium osmolarity by EnvZ and OmpR. EnvZ functions to sense environmental conditions and to relay this information to the DNA-binding protein OmpR. We have used a truncated EnvZ protein (EnvZ115), which is defective in sensory function but able to communicate with OmpR, to study the biochemical interactions between these two proteins and their effects on transcription from the ompF promoter. We show that purified EnvZ115 can phosphorylate OmpR in the presence of ATP. In addition, EnvZ115 stimulates the ability of OmpR to activate ompF transcription in vitro. Using antibodies specific for EnvZ, we have purified the wild-type protein and have shown that it is also an OmpR kinase. These results provide a prokaryotic example of a transmembrane sensory protein that functions as a protein kinase and suggest a mechanism by which EnvZ communicates with OmpR in signal transduction.
\end{abstract}

[Key Words: Autophosphorylation; membrane sensor; protein kinase; signal transduction]

Received February 7, 1989; revised version accepted March 7, 1989.

Synthesis of the major outer membrane porin proteins of Escherichia coli is regulated in response to changes in medium osmolarity. OmpF predominates in media of low osmolarity, whereas OmpC is made preferentially in high osmolarity (van Alphen and Lugtenberg 1977; Kawaji et al. 1979). This regulation is mediated at the level of transcription by the $o m p R$ and $e n v Z$ gene products (Hall and Silhavy 1979, 1981). EnvZ is localized to the cytoplasmic membrane (Forst et al. 1987). It functions to sense environmental conditions and to relay this information to OmpR, which binds upstream of the appropriate porin gene promoter (Norioka et al. 1986; Maeda and Mizuno 1988; Mizuno et al. 1988) and activates transcription.

In the last few years, it has become apparent that EnvZ and OmpR are members of a family of two-component sensory-processing systems (Ronson et al. 1987; Stock et al. 1989). Studies with two such systems, namely nitrogen utilization and chemotaxis, indicate that protein phosphorylation is involved in signal transduction. In these systems, a regulatory component $[\mathrm{NtrB}$ $\left(\mathrm{NR}_{\mathrm{II}}\right.$ ) or CheA] is autophosphorylated (Hess et al. 1988b; Weiss and Magasanik 1988). These proteins, in turn, function as protein kinases to transfer phosphate to effector components that mediate the adaptive response (Hess et al. 1988a,b; Keener and Kustu 1988; Weiss and Magasanik 1988; Wylie et al. 1988). The effector component $\mathrm{NtrC}\left(\mathrm{NR}_{\mathrm{I}}\right)$ activates transcription of the nitrogenregulated genes when phosphorylated (Ninfa and Magasanik 1986). The effector component CheY is thought to interact with the flagellar motor when phosphorylated to stimulate bacterial tumbling (Parkinson et al. 1983; Ninfa et al. 1988); phosphorylation of the effector CheB appears to stimulate its methylesterase activity, which modifies receptor sensitivity (Stewart and Dalquist 1988; Stock et al. 1989).

We have recently obtained evidence for an analogous mechanism in the porin regulon by demonstrating that the sensory component EnvZ can be phosphorylated in vitro in an ATP-dependent manner (Igo and Silhavy 1988). Here, we show that EnvZ is autophosphorylated and functions as a protein kinase with OmpR as substrate. Using purified bacterial components, we demonstrate that EnvZ stimulates activation of transcription by OmpR. These results provide a prokaryotic example of a transmembrane signaling protein that functions as a protein kinase.

\section{Results}

Biochemical analysis of the porin regulatory proteins is complicated because EnvZ, unlike NtrB and CheA, is an integral membrane protein that is present in low amounts in wild-type cells. In earlier studies, we used recombinant DNA techniques to overproduce a truncated EnvZ protein (EnvZ115) in which the first 38 amino acids of EnvZ are replaced with 8 amino acids of LacZ (Igo and Silhavy 1988). The mutant EnvZ115 protein differs from the wild type in at least one important way. Wild-type EnvZ is thought to be embedded in the 
membrane by two highly hydrophobic membrane-spanning segments, amino acids 16-46 and 163-179 (Forst et al. 1987). Accordingly, the protein has two domains: one comprised of amino acids $47-162$, which is localized at the exterior face of the cytoplasmic membrane and presumably functions in a sensory capacity, and the other comprised of a large carboxy-terminal domain, which faces the cytoplasm and functions in sensory transduction to communicate with OmpR. The deletion substitution of envZ115 disrupts the first hydrophobic membrane-spanning segment and prevents correct membrane assembly. As a result, EnvZ115 accumulates in the cytoplasm as an insoluble aggregate (see below). Not surprisingly, the mutant protein can no longer sense changes in medium osmolarity. However, in spite of its inability to sense changes in medium osmolarity, EnvZ115 retains the ability to communicate with OmpR. This is evidenced by complementation analysis, which shows that EnvZ115 can cause unregulated activation of both the $o m p F$ and $o m p C$ promoters (Igo and Silhavy 1988). In addition, as reported previously (Igo and Silhavy 1988), insoluble EnvZ115 (Fig. 1, lane 2) can be phosphorylated in the presence of $\left[\gamma^{-32} \mathrm{P}\right] \mathrm{ATP}$ (Fig. 2A, lane 1).

\section{OmpR can be phosphorylated by EnvZ115}

To determine whether EnvZ115 can function as a protein kinase, OmpR was purified as described in Materials and methods. OmpR is not labeled when incubated in the presence of $\left[\gamma^{-32} \mathrm{P}\right] \mathrm{ATP}$ (Fig. 2A, lane 2). However, when OmpR is added to a reaction containing insoluble EnvZ115 and $\left[\gamma^{-32} \mathrm{P}\right] \mathrm{ATP}$, label disappears from the band corresponding to EnvZ115 and a new phosphorylated band appears of the same size as OmpR (Fig. 2A, lane 3). This reaction occurs very rapidly and reaches equilibrium in $<6 \mathrm{sec}$. In addition, this activity of EnvZ115 is not promiscuous, because bovine serum albumin will not serve as a substrate (data not shown).

To confirm that the labeled protein is indeed OmpR, immunoprecipitation studies with anti-OmpR antiserum were performed. For this experiment, the transfer reaction was repeated and terminated by adding an equal volume of $2 \%$ SDS and $2 \mathrm{~mm}$ EDTA and heating the sample to $55^{\circ} \mathrm{C}$ for $5 \mathrm{~min}$. The sample was then spun for $10 \mathrm{~min}$ in a microfuge, and the soluble fraction used for immunoprecipitation (Stader et al. 1986). The immunoprecipitates were analyzed by gel electrophoresis followed by autoradiography. As shown in Figure 2B (lane $5)$, the new phosphate-labeled protein is precipitated by anti-OmpR antiserum. Because the phosphorylation of OmpR requires both EnvZ115 and ATP, we conclude that EnvZ115 can function as a protein kinase.

\section{Solubilization of EnvZ115}

To characterize the phosphorylation of EnvZ115 and OmpR in more detail, it was necessary to obtain EnvZ115 in a soluble form. In our original preparation of EnvZ115, the protein cosedimented with the particulate

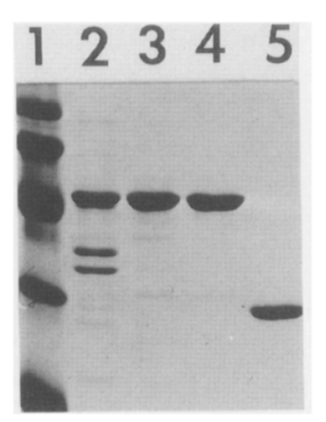

Figure 1. Analysis of EnvZ115 and OmpR preparations. Proteins were subjected to electrophoresis on a SDS-polyacrylamide gel $(12 \%)$ and visualized by staining with Coomassie blue. (Lane 1) Protein molecular weight standards: phosphorylase b $(97,400)$, bovine serum albumin $(68,000)$, ovalbumin $(43,000)$, carbonic anhydrase $(29,000), \beta$-lactoglobulin $(18,400)$; (lane 2) $12,500 \mathrm{~g}$ pellet, crude EnvZ115; (lane 3) membrane-free pellet fraction, insoluble EnvZ115; (lane 4) DOC-solubilized EnvZ115; (lane 5) OmpR.

membrane fraction (Igo and Silhavy 1988). Further analysis revealed that this was not due to an affinity between EnvZ115 and the membrane fraction. Rather, the EnvZ115 protein sedimented beneath the membrane fractions in a $40-55 \%$ sucrose step gradient as part of a protein aggregate. To obtain the EnvZ115 protein in a soluble form, we incubated the membrane-free pellet fraction (Fig. 1, lane 3 ) in PBS containing 2\% deoxycholate (DOC). After $30 \mathrm{~min}$, the mixture was diluted to

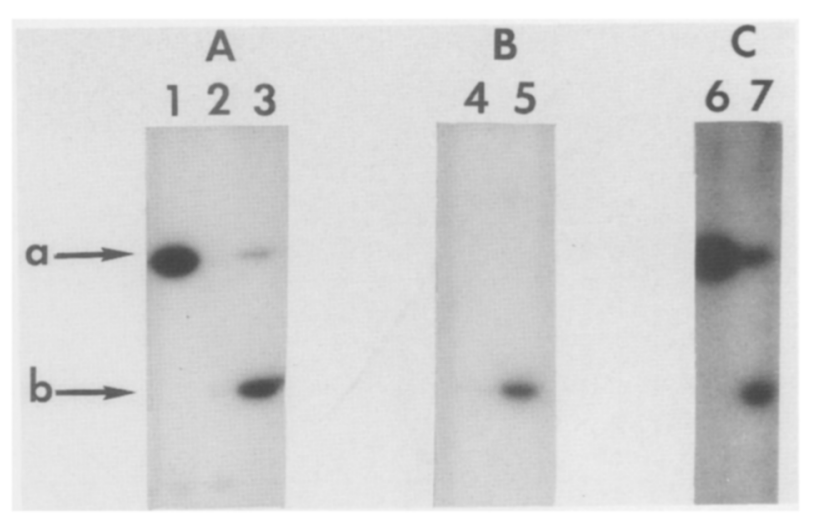

Figure 2. OmpR becomes phosphorylated when incubated in the presence of EnvZ115 and ATP. $(a \rightarrow \mid$ The position of EnvZ115; $(\mathrm{b} \rightarrow)$ the position of OmpR. $(A)$ Autoradiogram of insoluble EnvZ115 (lane 1) or OmpR (lane 2) incubated in the presence of $5 \mathrm{mM} \mathrm{MgCl} 2,50 \mathrm{mM} \mathrm{KCl}$, and $0.4 \mathrm{mM}\left[\gamma^{-32} \mathrm{P}\right] \mathrm{ATP}$ (1000 cpm/pmole). (Lane 3) OmpR was added to a reaction identical to that shown in lane 1. $(B)$ Autoradiogram of OmpR phosphate after immunoprecipitation. OmpR was incubated in the presence of insoluble EnvZ115 and $0.4 \mathrm{~mm}\left[\gamma^{-32} \mathrm{P}\right] \mathrm{ATP}$ and then immunoprecipitated using preimmune serum (lane 4) or rabbit anti-OmpR antiserum (lane 5). $(C)$ Autoradiogram of DOC-solubilized EnvZ115 and/or OmpR incubated in the presence of $5 \mathrm{mM} \mathrm{MgCl}_{2}, 50 \mathrm{mM} \mathrm{KCl}$, and $0.4 \mathrm{mM}\left[\gamma^{-32}\right.$ P]ATP (1000 cpm/pmole). (Lane 6) EnvZ115 alone; (lane 7) EnvZ115 and OmpR. 
give a final DOC concentration of $0.2 \%$, and the solubilized material was recovered in the supernatant after centrifugation at $100,000 \mathrm{~g}$ for $30 \mathrm{~min}$ at $4^{\circ} \mathrm{C}$ (Fig. 1, lane 4). This procedure allows partial solubilization, $\sim 30 \%$ of the total. Solubilized EnvZ115 can be phosphorylated in the presence of $\left[\gamma^{-32}\right.$ P]ATP (Fig. 2C, lane 6) and can be used to phosphorylate OmpR (Fig. 2C, lane 7).

\section{EnvZ115 is autophosphorylated}

On the basis of the analogy with $\mathrm{NtrB}$ and CheA and the fact that phosphorylation of EnvZ115 is observed following substantial purification, we suspected that EnvZ was autophosphorylated. To verify this, the initial rate of phosphorylation was examined over a 16-fold range of EnvZ115 concentrations in the presence of $0.4 \mathrm{~mm}$ $\left[\gamma^{-32}\right.$ P]ATP. As with CheA and NtrB, the addition of 50 $\mathrm{mM} \mathrm{KCl}$ results in a significant stimulation in the phosphorylation of EnvZ115. Because the phosphorylation reaction occurs too rapidly under these conditions for a rate to be determined accurately, we slowed the reaction by lowering the $\mathrm{KCl}$ concentration. These conditions are similar to those used by Hess et al. (1988b) to show that CheA is phosphorylated via an intramolecular reaction. As can be seen in Figure 3, the phosphorylation rate per milligram of EnvZ115 is independent of the concentration of EnvZ115, indicating that EnvZ115 is phosphorylated in an intramolecular reaction.

Additional evidence that EnvZ115 is autophosphorylated comes from the results of an immune complex kinase reaction (Collett et al. 1980). In these experiments,

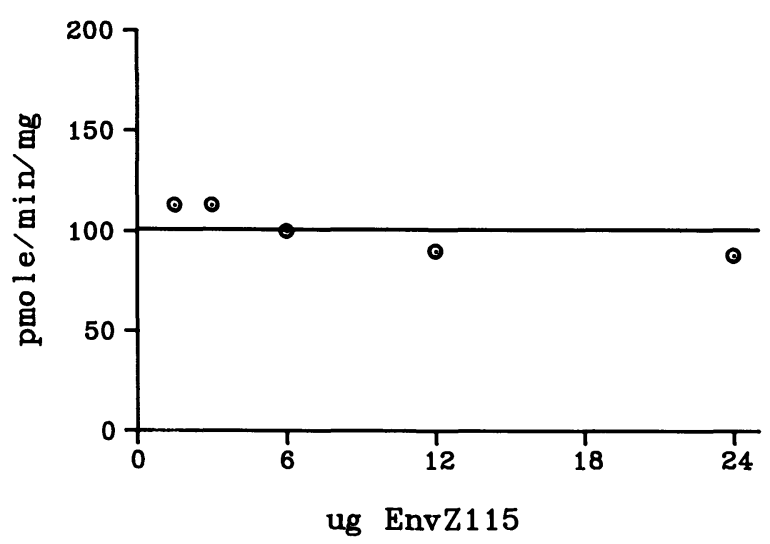

Figure 3. EnvZ115 phosphorylation is independent of protein concentration. The initial rate of phosphorylation for various concentrations of solubilized EnvZ115 was compared over a 16-fold range of protein concentrations as described by Hess et al. (1988b). EnvZ115 was incubated in the presence of $0.1 \mathrm{~mm}$ $\left[\gamma^{-32} \mathrm{P}\right] \mathrm{ATP}$ and $10 \mathrm{~mm} \mathrm{MgCl}_{2}$. An aliquot of the reaction mixture was removed every $15 \mathrm{sec}$ for the first minute, and the number of TCA-precipitable counts in each sample was measured. The rate at each EnvZ115 concentration was calculated by plotting the amount of TCA-precipitable phosphate versus time and then determining the slope. This rate, which is expressed in picomoles per minute per milligram of EnvZ, was plotted against the amount of EnvZ115 in each reaction.
EnvZ115 was first immunoprecipitated with anti-EnvZ antiserum, using the procedure of Collett et al. (1980; see also Materials and methods). The immunoprecipitate was suspended in $50 \mu l 10 \mathrm{~mm}$ Tris $(\mathrm{pH} 7.4), 5 \mathrm{~mm}$ $\mathrm{MgCl}_{2}$, and $50 \mathrm{mM} \mathrm{KCl}$ and incubated in the presence of $\left.0.4 \mathrm{mM}\left[\gamma^{-32}\right]\right]$ ATP for $10 \mathrm{~min}$. The reaction was analyzed by gel electrophoresis, followed by autoradiography (Fig. 4). Because this antiserum is specific for EnvZ (Igo and Silhavy 1988), and in view of the physical constraints imposed on EnvZ in the immune complex, it seems unlikely that the phosphorylation reaction is occurring by an intermolecular reaction. Therefore, based on this experiment and on our ability to dilute the EnvZ115 protein without affecting specific activity, we conclude that EnvZ115 is autophosphorylated.

\section{EnvZ115 stimulates OmpR-dependent transcription of ompF in vitro}

To monitor transcription of ompF in vitro, we used plasmid pIP23. This plasmid contains the ompF promoter positioned upstream from a strong $\rho$-independent terminator, allowing the production of a 519-bp transcript. In the absence of OmpR and EnvZ115, few transcription complexes were initiated at the $o m p F$ promoter when the supercoiled template $(10 \mathrm{nM})$ was incubated with excess core RNA polymerase, sigma 70 , and the nucleotide triphosphates ATP, CTP, and GTP (Fig. 5, lane 1). Addition of purified $\mathrm{OmpR}$ to the reaction mixture at $3.8 \mu \mathrm{M}$ resulted in a large increase in the amount of transcription initiated at the ompF promoter (Fig. 5, lane 2). An equal quantity of OmpR that had been heated

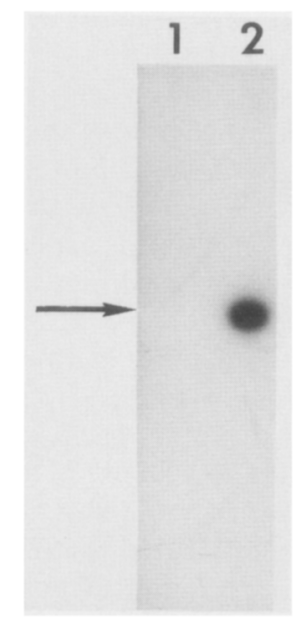

Figure 4. EnvZ115 is autophosphorylated. DOC-solubilized EnvZ115 was immunoprecipitated using preimmune serum (lane 1) or rabbit anti-EnvZ antiserum (lane 2). The immunoprecipitates were then suspended in $10 \mathrm{mM}$ Tris- $\mathrm{HCl}(\mathrm{pH} 7.4), 5$ $\mathrm{mM} \mathrm{MgCl}_{2}$, and $50 \mathrm{mM} \mathrm{KCl}$, and the kinase reaction was initiated by the addition of $0.4 \mathrm{~mm}\left[\gamma^{-32} \mathrm{P}\right] \mathrm{ATP}(1000 \mathrm{cpm} / \mathrm{pmole})$. The samples were then analyzed on a SDS-polyacrylamide gel $(12 \%)$, followed by autoradiography. $(\rightarrow)$ The position of EnvZ115. 
to $90^{\circ} \mathrm{C}$ for $2 \mathrm{~min}$ and cooled showed no activity (Fig. 5, lane 10). Similar, although less dramatic, results were obtained previously when high concentrations of OmpR were used with linear templates (Norioka et al. 1986). Dilution of our OmpR preparation caused loss of this activity. At $1.9 \mu \mathrm{M}$ OmpR, transcription from the $\mathrm{ompF}$ promoter was barely detectable and none was observed at $380 \mathrm{~nm}$ or less (Fig. 5, lanes 3-6).

Because EnvZ115 function is required for activation of $o m p F$ transcription in vivo, we tested whether this requirement could be demonstrated in vitro. For these experiments, EnvZ115 (200 nM) was added to a series of transcription reactions containing varying concentrations of OmpR. Results shown in Figure 5 (lanes 7-9) indicate that EnvZ115 causes a marked stimulation of transcription initiation when OmpR concentrations are

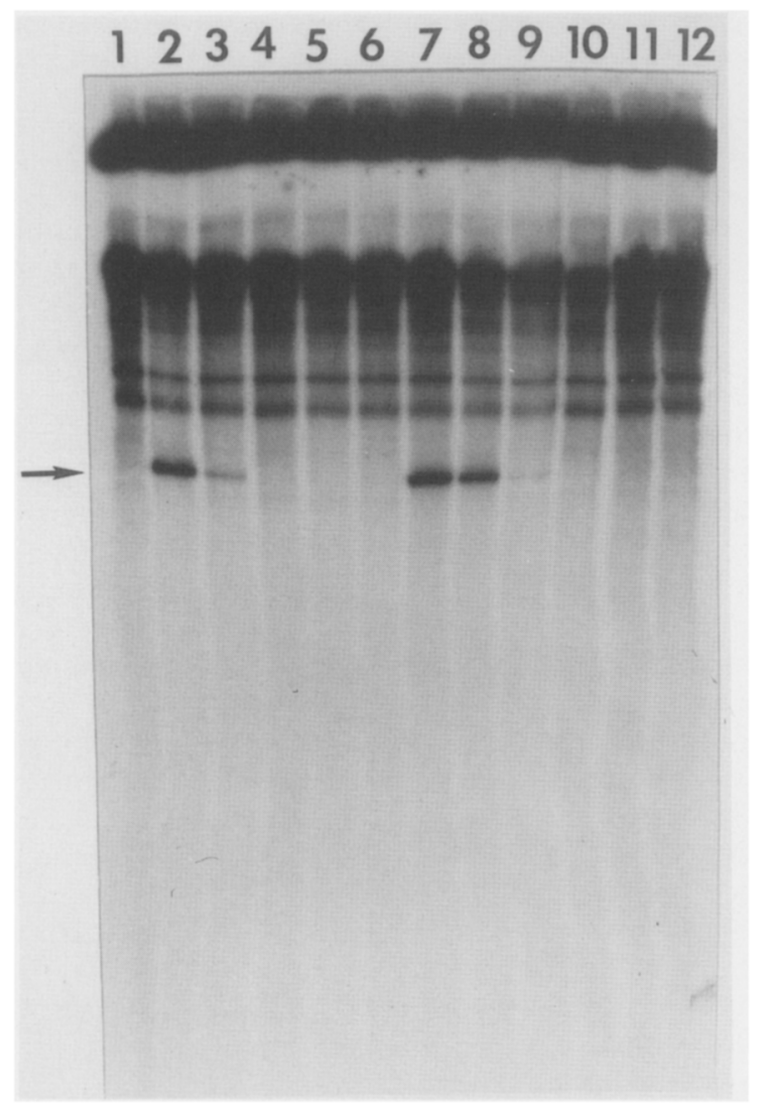

Figure 5. Transcription from the $o m p F$ promoter. All reaction mixtures contained template (10 $\mathrm{nM})$, core RNA polymerase (100 nM), and sigma 70 (100 nM). Other protein concentrations are as follows: (Lane 1) No additional proteins; (lane 2) OmpR at $3.80 \mu \mathrm{M}$; (lane 3) OmpR at $1.9 \mu \mathrm{M}$; (lane 4) $\mathrm{OmpR}$ at $380 \mathrm{nM}$; (lane 5) OmpR at $190 \mathrm{nM}$; (lane 6) OmpR at $38 \mathrm{nM}$; (lane 7) OmpR at $380 \mathrm{nM}$ and EnvZ115 at $200 \mathrm{nM}$; (lane 8) OmpR at 190 $\mathrm{nM}$ and EnvZ115 at $200 \mathrm{nM}$; (lane 9) OmpR at $38 \mathrm{nM}$ and

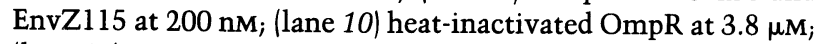
(lane 11) OmpR at $380 \mathrm{nM}$ and heat-inactivated EnvZ115 at 200 nM; (lane 12) EnvZ115 at $200 \mathrm{nM}$. Transcripts were detected by gel electrophoresis and autoradiography. $(\rightarrow)$ The position of the $o m p F$ transcript; in separate experiments, we determined that this transcript is the appropriate size (not shown). limiting. Such stimulation was not observed when the EnvZ115 preparation was heated to $90^{\circ} \mathrm{C}$ for $2 \mathrm{~min}$ and then cooled or when OmpR was omitted (Fig. 5, lanes 11 and 12). These results indicate that purified EnvZ115 acts in concert with $\mathrm{OmpR}$ to activate transcription from the $o m p F$ promoter.

\section{Wild-type EnvZ is autophosphorylated}

The experiments described to this point use EnvZ115, which can be obtained in quantity. Although this mutant protein retains the ability to communicate with OmpR, it is not fully functional, and this precludes a detailed analysis of the physiological significance of the autophosphorylation and phosphotransfer reactions. Our success with the immune complex kinase reaction described above suggested a means to determine whether the wild-type EnvZ protein behaves in a similar fashion. For these experiments, cells were grown to late log phase, harvested, suspended in Hermann's immunoprecipitation buffer, and passed through a French press twice. The soluble fraction was then collected and used in the immune complex kinase reaction. To make it easier to detect low levels of phosphorylated EnvZ, 25 $\mu \mathrm{Ci}$ of $\left[\gamma^{-32} \mathrm{P}\right] \mathrm{ATP}$ was used in each reaction.

Figure 6 shows the results of the immune complex kinase reaction performed with the following strains: MC4100, which contains envZ in single copy in the chromosome (Fig. 6A, lane 2); MC4100/pIP71, which contains env $Z$ on a low-copy-number plasmid (Fig. 6A, lane 4); and MC4100/pIP50, which contains envZ on a

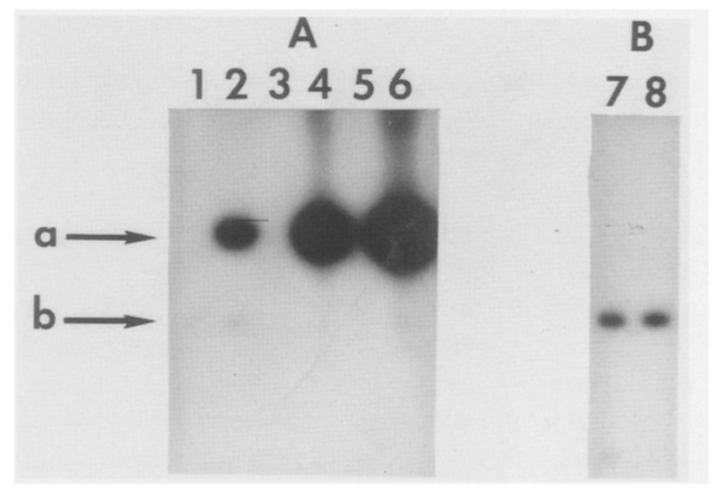

Figure 6. Wild-type EnvZ is autophosphorylated. Lysates were prepared as described in Materials and methods, and EnvZ was immunoprecipitated with preimmune serum (lanes $1,3,5,7$ ) or with anti-EnvZ antiserum (lanes 2, 4, 6, 8). The immunoprecipitates were suspended in $10 \mathrm{mM}$ Tris- $\mathrm{HCl}(\mathrm{pH} 7.4), 5 \mathrm{~mm}$ $\mathrm{MgCl}_{2}$, and $50 \mathrm{mM} \mathrm{KCl}$, and the kinase reaction was initiated by the addition of $70 \mathrm{nM}\left[\gamma^{-32} \mathrm{P}\right] \mathrm{ATP}\left(6 \times 10^{6} \mathrm{cpm} / \mathrm{pmole}\right)$. The samples were then analyzed on a SDS-polyacrylamide gel $(12 \%)$, followed by autoradiography. $(a \rightarrow)$ The position of EnvZ; $(\mathrm{b} \rightarrow)$ The position of a band that appears upon overexposure when either the preimmune serum or the anti-EnvZ antiserum is used. The autoradiogram in $B$ was exposed 20 times longer than that in $A .(A)$ (Lanes 1,2) MC4100; (lanes 3,4) MC4100/ pIP71; (lanes 5,6) MC4100/pIP50. (B) (Lanes 7,8) MC4100 envZ60 : : Tn10 
high-copy-number plasmid (Fig. 6A, lane 6). A labeled band appears that increases in intensity as the copy number of envZ increases. As a control, this analysis was also performed on the strain MC4100 envZ60 : : Tn10 (Slauch et al. 1988), which carries a Tn10 insertion in envZ (Fig. 6B). Although a number of labeled bands appear upon overexposure, these bands are also found using the preimmune serum, indicating that they do not correspond to EnvZ. These experiments demonstrate that wild-type EnvZ is autophosphorylated, as predicted based on studies with EnvZ115.

\section{OmpR can be phosphorylated by EnvZ in an immune complex}

Results with EnvZ115 suggest that env $Z$ communicates with $O m p R$ by phosphorylation. To verify this prediction for wild-type EnvZ, we examined the effect of adding purified $O m p R$ to phosphorylated wild-type EnvZ present in the immune complex. Figure 7 shows that the addition of OmpR resulted in the dephosphorylation of EnvZ phosphate. (No significant dephosphorylation of EnvZ phosphate was observed in the absence of OmpR; data not shown.) Furthermore, a new labeled band appears that corresponds to OmpR. As with EnvZ115, this reaction occurs very rapidly and reaches equilibrium in $<6 \mathrm{sec}$, demonstrating that wild-type EnvZ is an OmpR kinase.

\section{Discussion}

The EnvZ protein of $E$. coli appears to function as an environmental sensor relaying information regarding medium osmolarity to the cytoplasm. Although we do not yet know what EnvZ senses, it seems likely that the sensory functions of the protein reside in the domain that faces the periplasm (amino acids 47-162), as mutations such as envZ115 that disrupt this domain cause unregulated porin gene expression (Igo and Silhavy 1988). The carboxy-terminal domain of EnvZ functions in signal transduction. This domain appears to remain largely intact in the mutant EnvZ115 protein, and we have found two biochemical activities mediated by this portion of the molecule. First, the carboxy-terminal domain catalyzes an ATP-dependent autophosphorylation. Second, it acts as a protein kinase to catalyze the phosphorylation of the DNA-binding protein OmpR. Because the wild-type EnvZ protein shares these biochemical activities, it provides an example of a transmembrane sensory protein with kinase activity.

Although this is the first prokaryotic example of a transmembrane sensory protein with kinase activity, we predict that this finding will prove more general, based on amino acid sequence similarities. EnvZ is related to a large number of bacterial proteins that function in signal transduction. These proteins (EnvZ, VirA, DctB, PgtB, UhpB, PhoR, PhoM, CpxA, FixL, DegS, NtrB, and CheA, recently reviewed in Ronson et al. 1987; Stock et al. 1989 ) share a 225 -amino-acid domain that usually is located at the carboxyl terminus. All but the last three ap-

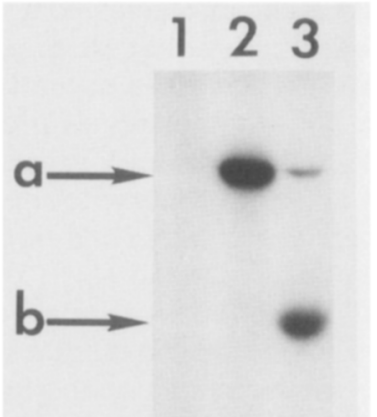

Figure 7. OmpR can be phosphorylated by EnvZ in an immune complex. A lysate from MC4100/pIP50 was prepared as described in Materials and methods, and EnvZ was immunoprecipitated with preimmune serum (lane 1) or with anti-EnvZ antiserum (lanes 2,3). The immunoprecipitates were suspended in $10 \mathrm{~mm}$ Tris- $\mathrm{HCl}(\mathrm{pH} 7.4), 5 \mathrm{~mm} \mathrm{MgCl}$, and $50 \mathrm{mM} \mathrm{KCl}$, and the kinase reaction was initiated by the addition of $0.4 \mathrm{~mm}$ $\left[\gamma^{-32}\right.$ P]ATP (8000 cpm/pmole). After $10 \mathrm{~min}, \mathrm{OmpR}$ was added to one of the samples (lane 3). The samples were then analyzed on a SDS-polyacrylamide gel $(12 \%)$, followed by autoradiography. $(\mathrm{a} \rightarrow)$ The position of EnvZ; $(\mathrm{b} \rightarrow)$ the position of OmpR.

pear to be membrane proteins with a unique amino-terminal periplasmic domain flanked by two hydrophobic membrane-spanning segments in the primary sequence. Thus, all of these membrane proteins probably share a common topology as well. By analogy to EnvZ, it seems likely that the amino-terminal domain of these proteins performs a sensory function and that the carboxyl terminus signals by a mechanism involving phosphorylation.

Genetic analysis of porin regulation suggests that EnvZ communicates with OmpR and that the regulatory activities of EnvZ require this communication. Similarly, OmpR has very little activity in vivo in the absence of EnvZ; thus, OmpR function requires communication with envZ as well (Garrett et al. 1983). Our experiments using purified components show that EnvZ115 stimulates the ability of OmpR to activate transcription from the ompF promoter. We performed our transcription experiments under conditions where the phosphorylation of OmpR by EnvZ115 occurs. Because at least one aspect of EnvZ-OmpR communication involves the protein kinase activity of EnvZ, it seems likely that $o m p F$ transcription is stimulated by the formation of OmpR phosphate. EnvZ and OmpR probably resemble NtrB and NtrC in this regard, and although our studies are not yet complete, we expect that the mechanistic features of the relevant biochemical reactions will be analogous (Ninfa and Magasanik 1986; Keener and Kustu 1988; Weiss and Magasanik 1988).

Although EnvZ and OmpR are similar to NtrB and $\mathrm{NtrC}$ in terms of transcriptional activation, purified OmpR has some activity in the absence of EnvZ (Fig. 5; Norioka et al. 1986), whereas NtrC function requires 
NtrB in vitro (Ninfa and Magasanik 1986). Because OmpR was purified from cells that should contain high levels of EnvZ, our preparation may contain some OmpR phosphate. This explanation would require that OmpR phosphate be quite stable in marked contrast to NtrC phosphate (Keener and Kustu 1988; Weiss and Magasanik 1988). Alternatively, unlike NtrC, OmpR may have inherent ability to activate transcription. Indeed, strains that lack EnvZ express ompF at low levels, and this expression requires OmpR (Garrett et al. 1983).

Although the demonstration of EnvZ-OmpR communication by phosphorylation and the stimulation of OmpR-dependent transcription of ompF by EnvZ115 are important advances, it is not possible to predict how this relates to the fluctuation of $o m p F$ and $o m p C$ transcription in response to environmental changes. In vivo, EnvZ functions to both activate and regulate porin gene expression. Our results argue that phosphorylation is involved in activation. Whether or not phosphorylation plays a role in regulation remains to be determined.

The immune complex kinase reaction, a method developed for the analysis of eukaryotic protein kinases such as Src (Collett et al. 1980), has proved to be an especially useful experimental tool. This method permits a rapid, one-step purification of functional EnvZ, a protein that is membrane bound and present in low amounts. Further application of this technique should be useful for the analysis of EnvZ mutant proteins and for the examination of other signal transduction systems related to EnvZ and OmpR by sequence similarities.

\section{Materials and methods}

Overproduction of EnvZ115, EnvZ, and OmpR

EnvZ115 was produced using the plasmid pSG115 (Garrett 1986; Igo and Silhavy 1988). The plasmid pIP71, which is a derivative of the low-copy-number plasmid pRAM1005 (R. Misra, pers. comm.), carries the $o m p B$ operon on a $8.4-\mathrm{kb} B a m H I$ fragment (Taylor et al. 1983). To overproduce both OmpR and EnvZ, the 3.5-kb SmaI-Sall fragment carrying the entire ompB operon was inserted downstream of the lac promoter in the plasmid pMLB1107 (M. Berman, pers. comm.), resulting in pIP50. In this plasmid, the $\operatorname{omp} B$ operon can be transcribed from both the $о m p B$ promoter and, in the presence of isopropyl-thio- $\beta$-galactoside (IPTG), from the lac promoter.

\section{Purification of EnvZ115}

The EnvZ115 protein was produced at high levels in a strain containing the plasmid pSG115, as decribed previously (Igo and Silhavy 1988). Following growth, cells were suspended in phosphate-buffered saline (PBS, Dulbecco and Vogt 1954) and passed through a French press three times $(15,000 \mathrm{psi})$. The lysate was then spun at $12,500 \mathrm{~g}$ for $30 \mathrm{~min}$. The resulting pellet was suspended in $2.5 \%$ sucrose and $5 \mathrm{mM}$ EDTA $(\mathrm{pH} 7.5)$ and layered onto a $40-55 \%$ sucrose step gradient (Chen et al. 1988). Centrifugation was carried out at $50,000 \mathrm{~g}$ for $19 \mathrm{hr}$. The purified pellet fraction is termed insoluble EnvZ115. Solubilization of EnvZ115 was accomplished by suspending the pellet fraction in
$5 \mathrm{ml}$ of PBS containing 2\% DOC. After $30 \mathrm{~min}$, the mixture was diluted to give a final DOC concentration of $0.2 \%$, and the solubilized material was recovered in the supernatant after centrifugation at $100,000 \mathrm{~g}$ for $30 \mathrm{~min}$ at $4^{\circ} \mathrm{C}$. An SDS-polyacrylamide gel $(12 \%)$ displaying EnvZ115 at various stages during the purification is shown in Figure 1 (lanes 2-4). On the basis of this analysis, we judge the solubilized EnvZ115 to be $>95 \%$ pure.

\section{Purification of the OmpR protein}

MC1000 (Silhavy et al. 1984) containing the plasmid pIP50 was grown in 10 liters of $\mathrm{T}$ broth to the mid-exponential phase of growth, and high-level OmpR synthesis was induced by the addition of $1 \mathrm{~mm}$ IPTG. After $3 \mathrm{hr}$, the cells were collected by centrifugation and washed with PBS, and the pellet was stored at $-70^{\circ} \mathrm{C}$. OmpR was purified, using the method described by Jo et al. (1986), except that the Sephacryl S-200 column chromatography was omitted. An SDS-polyacrylamide gel (12\%) displaying OmpR after this purification is shown in Figure 1 (lane 5). On the basis of this analysis, we judge OmpR to be $>95 \%$ pure.

\section{Phosphorylation of EnvZ115}

Unless otherwise noted, EnvZ115 was phosphorylated in a $20-\mu l$ reaction containing $0.4 \mathrm{mM}\left[\gamma^{-32} \mathrm{P}\right] \mathrm{ATP}$ (1000 cpm/ pmole), $50 \mathrm{~mm}$ Tris- $\mathrm{HCl}$ (pH 7.6), $50 \mathrm{mM} \mathrm{KCl}, 10 \mathrm{~mm} \mathrm{MgCl}_{2}, 1$ mM dithiothreitol (DTT), and $0.1 \mathrm{~mm}$ EDTA. The reaction was initiated by the addition of the ATP, incubated at room temperature for $10 \mathrm{~min}$, and terminated by the addition of $8.3 \mu \mathrm{l}$ of SDS sample buffer [124 mM Tris- $\mathrm{HCl}(\mathrm{pH} 6.8), 4 \%$ SDS, $8 \%$ (vol/vol) 2-mercaptoethanol, 20\% (vol/vol) glycerol]. The samples were heated to $55^{\circ} \mathrm{C}$ for $3 \mathrm{~min}$ and subjected to electrophoresis on a SDS-polyacrylamide gel $(12 \%)$, and the labeled proteins were detected by autoradiography.

\section{Immune complex kinase reaction}

The immune complex kinase reaction was performed using the procedure of Collett et al. (1980). In this procedure, $15 \mu \mathrm{g}$ of EnvZ115 was added to $0.65 \mathrm{ml}$ of Hermann's immunoprecipitation buffer [1\% NP-40, $0.5 \%$ sodium DOC, $100 \mathrm{~mm} \mathrm{NaCl}, 10$ $\mathrm{mm}$ Tris (pH 7.2), $1 \mathrm{~mm}$ EDTA]. Rabbit anti-EnvZ antiserum or preimmune serum $(5 \mu \mathrm{l})$ was added to the above mixture, and the samples were mixed gently at $4^{\circ} \mathrm{C}$ for $1 \mathrm{hr}$. Fifty microliters of formalin-treated Staph A (BRL, Immunoprecipitin) was added to the mixture, and the samples were mixed gently again for 1 $\mathrm{hr}$ at $4^{\circ} \mathrm{C}$. The immunoprecipitate was pelleted, washed twice with immunoprecipitation buffer, washed once with $100 \mathrm{~mm}$ $\mathrm{NaCl}$ and $10 \mathrm{~mm}$ Tris- $\mathrm{HCl}(\mathrm{pH} \mathrm{7.4)}$, and suspended in $50 \mu \mathrm{l} 10$ $\mathrm{mM}$ Tris- $\mathrm{HCl}(\mathrm{pH} 7.4), 5 \mathrm{mM} \mathrm{MgCl}_{2}$, and $50 \mathrm{~mm} \mathrm{KCl}$. The kinase reaction was initiated by the addition of $0.4 \mathrm{~mm}$ [ $\left.\gamma^{-32} \mathrm{P}\right]$ ATP $(1000 \mathrm{cpm} / \mathrm{pmole})$, incubated at room temperature for $10 \mathrm{~min}$, and the reaction was terminated by washing the immunoprecipitate with $0.5 \mathrm{ml}$ of cold STE $[100 \mathrm{mM} \mathrm{NaCl}, 10$ mM Tris (pH 7.4), 1 mM EDTA]. EnvZ115 was eluted from the immunoprecipitate by the addition of SDS sample buffer.

\section{Phosphorylation of wild-type EnvZ}

MC4100 (Silhavy et al. 1984), MC4100 containing the plasmid pIP71, and MC4100 containing the plasmid pIP50 were grown to late $\log$ in $50 \mathrm{ml}$ of Luria broth (no IPTG was added), har- 
vested, washed once in $\mathrm{PBS}$, and stored overnight at $-20^{\circ} \mathrm{C}$. The cells were suspended in $3 \mathrm{ml}$ Hermann's immunoprecipitation buffer and passed through a French press twice. The lysate was spun at $100,000 \mathrm{~g}$ for $30 \mathrm{~min}$, and $0.65 \mathrm{ml}$ of the supernatant was used in the immune complex kinase reaction described above.

\section{Transcription assays}

The transcription template was derived from the plasmid pTE103 (Elliott and Geiduschek 1984), which contains the multiple cloning site from pUC8 positioned $300 \mathrm{bp}$ upstream of a strong $\rho$-independent transcriptional terminator from bacteriophage T7. The 480-bp EcoRI-BamHI fragment from pORF2 (Weinstock et al. 1983), containing the $O m p F$ promoter, was inserted into EcoRI-BamHI-digested pTE103 to generate pIP23; in this plasmid, the $o m p F$ transcription initiation site is positioned $519 \mathrm{bp}$ upstream from the $\mathrm{T} 7$ terminator.

The protocol for the single cycle transcription assay is essentially identical to that used previously in the study of $\operatorname{gln} A$ transcription (Ninfa et al. 1989). The assay measures the number of heparin-resistant transcription complexes formed in the presence of ATP, GTP, and CTP. Core RNA polymerase (100 nM), sigma 70 (100 nM), supercoiled pIP23 (10 nM), the nucleotides ATP, CTP, and GTP (0.4 mM each), buffer [final concentrations: $50 \mathrm{~mm}$ Tris- $\mathrm{HCl}(\mathrm{pH} 7.6), 50 \mathrm{~mm} \mathrm{KCl}, 10 \mathrm{~mm}$ $\mathrm{MgCl}_{2}, 1 \mathrm{mM}$ DTT, $0.1 \mathrm{~mm}$ EDTA], and additional proteins as indicated were incubated for $20 \mathrm{~min}$ at $37^{\circ} \mathrm{C}$. A mixture containing heparin and labeled UTP $(0.1 \mathrm{mM})$ was then added, and the incubation was continued for an additional $10 \mathrm{~min}$ at $37^{\circ} \mathrm{C}$ to allow the formation of full-length labeled transcripts. The reactions were then stopped by the addition of EDTA. The transcripts were recovered by ethanol precipitation in the presence of tRNA, which serves as a carrier, subjected to electrophoresis on $7 \mathrm{M}$ urea-4\% acrylamide gels, and detected by autoradiography, as described previously (Ninfa et al. 1989).

\section{Acknowledgments}

We thank M. Resh for suggesting use of the immune complex kinase reaction and for many helpful discussions. We also thank D. Dolinger, G. Zubay, and J. Stock for useful discussions. We are grateful to J. Slauch for assistance in making the rabbit anti-OmpR antiserum and Carol Gross for providing sigma 70 . This research was supported by a U.S. Public Health Service grant (GM-35791) to T.J.S. from the National Institutes of Health (NIH). M.M.I. was supported by a Damon RunyonWalter Winchell Cancer Fund Fellowship (DRG-942). A.J.N. was supported by a grant from NIH.

\section{References}

Chen, H., T. Hoey, and G. Zubay. 1988. Purification and properties of the Drosophila zen protein. Mol. Cell. Biochem. 79: $181-189$

Collett, M.S., A.F. Purchio, and R.L. Erikson. 1980. Avian sarcoma virus-transforming protein, pp60 ${ }^{\text {src }}$, shows protein $\mathrm{ki}$ nase activity specific for tyrosine. Nature 285: 167-169.

Dulbecco, R. and M. Vogt. 1954. Plaque formation and isolation of pure lines with poliomyelitis viruses. I. Exp. Med. 99: $167-182$.

Elliott, T. and E.P. Geiduschek. 1984. Defining a bacteriophage T4 late promoter: Absence of a ' $-35^{\prime}$ region. Cell 36: 211 219.

Forst, S., D.E. Comeau, S. Norioka, and M. Inouye. 1987. Localization and membrane topology of EnvZ, a protein involved in osmoregulation of OmpF and OmpC in Escherichia coli. J. Biol. Chem. 262: 16433-16438.

Garrett, S. 1986. Ph.D dissertation, "Genetic studies on the synthesis of the major outermembrane porin proteins of $E$. coli K12." The Johns Hopkins University, Baltimore, Maryland.

Garrett, S., R.K. Taylor, and T.J. Silhavy. 1983. Isolation and characterization of chain-terminating nonsense mutations in a porin regulator gene, envZ. J. Bacteriol. 156: 62-69.

Hall, M.N. and T.J. Silhavy. 1979. Transcriptional regulation of Escherichia coli K-12 major outer membrane protein 1b. J. Bacteriol. 140: 342-350.

- 1981. The ompB locus and the regulation of the major outer membrane porin proteins of Escherichia coli K12. J. Mol. Biol. 146: 23-43.

Hess, J.F., R.B. Bourret, and M.I. Simon. 1988a. Histidine phosphorylation and phosphoryl group transfer in bacterial chemotaxis. Nature 336: 139-143.

Hess, J.F., K. Oosawa, N. Kaplan, and M.I. Simon. 1988b. Phosphorylation of three proteins in the signaling pathway of bacterial chemotaxis. Cell 53: 79-87.

Igo, M.M. and T.J. Silhavy. 1988. EnvZ, a transmembrane environmental sensor of Escherichia coli K-12 is phosphorylated in vitro. J. Bacteriol. 170: 5971-5973.

Jo, Y.L., F. Nara, S. Ichihara, T. Mizuno, and S. Mizushima. 1986. Purification and characterization of the OmpR protein, a positive regulator involved in osmoregulatory expression of the ompF and ompC genes in Escherichia coli. I. Biol. Chem. 261: 15252-15256.

Kawaji, H., T. Mizuno, and S. Mizushima. 1979. Influence of molecular size and osmolarity of sugars and dextrans on the synthesis of outer membrane proteins O-8 and O-9 of Escherichia coli K-12. I. Bacteriol. 140: 843-847.

Keener, J. and S. Kustu. 1988. Protein kinase and phosphoprotein phosphatase activities of nitrogen regulatory proteins NTRB and NTRC of enteric bacteria: Roles of conserved amino-terminal domain of NTRC. Proc. Natl. Acad. Sci. 85: 4976-4980.

Maeda, S. and T. Mizuno. 1988. Activation of the ompC gene by the OmpR protein of Escherichia coli. J. Biol. Chem. 263: $14629-14633$.

Mizuno, T., M. Kato, Y.L. Jo, and S. Mizushima. 1988. Interaction of OmpR, a positive regulator, with the osmoregulated ompC and ompF genes of Escherichia coli. J. Biol. Chem. 263: $1008-1012$.

Ninfa, A.J. and B. Magasanik. 1986. Covalent modification of the $g \ln G$ product, $\mathrm{NR}_{\mathrm{I}}$, by the $g \ln L$ product, $\mathrm{NR}_{\mathrm{I}}$, regulates the transcription of the $\ln A L G$ operon in Escherichia coli. Proc. Natl. Acad. Sci. 83: 5909-5913.

Ninfa, A.J., E. Brodsky, and B. Magasanik. 1989. Role of $\mathrm{NR}_{\mathrm{I}^{-}}$ phosphate in the activation of transcription initiation from the nitrogen regulated promoter $g \ln A p 2$. In $D N A$-protein interactions in transcription (ed. J. Gralla), pp. 43-52. UCLA Symp. on Mol. and Cell Biology. Vol 95. Alan R. Liss, New York.

Ninfa, A.J., E.G. Ninfa, A.N. Lupas, A.M. Stock, B. Magasanik, and J. Stock. 1988. Crosstalk between bacterial chemotaxis signal transduction proteins and the regulators of transcription of the Ntr regulon: Evidence that chemotaxis and nitrogen assimilation are controlled by a common phosphotransfer mechanism. Proc. Natl. Acad. Sci. 85: 5492-5496.

Norioka, S., G. Ramakrishnan, K. Ikenaka, and M. Inouye. 1986. Interaction of a transcriptional activator, OmpR, with reciprocally osmoregulated genes, $o m p F$ and $o m p C$, of Escherichia coli. J. Biol. Chem. 261: 17113-17119.

Parkinson, J.S., S.R. Parker, P.B. Talbert, and S.E. Houts. 1983. 
Interactions between chemotaxis genes and flagellar genes in Escherichia coli. J. Bacteriol. 155: 265-274.

Ronson, C.W., B.T. Nixon, and F.M. Ausubel. 1987. Conserved domains in bacterial regulatory proteins that respond to environmental stimuli. Cell 49: 579-581.

Silhavy, T.J., M.L. Berman, and L.W. Enquist. 1984. Experiments in gene fusions. Cold Spring Harbor Laboratory, Cold Spring Harbor, New York.

Slauch, J.M., S. Garrett, D.E. Jackson, and T.J. Silhavy. 1988. EnvZ functions through OmpR to control porin gene expression in Escherichia coli K-12. J. Bacteriol. 170: 439441.

Stader, J., S.A. Benson, and T.J. Silhavy. 1986. Kinetic analysis of $1 a m B$ mutants suggests the signal sequence plays multiple roles in protein export. J. Biol. Chem. 261: 1507515080.

Stewart, R.C. and F.W. Dalquist. 1988. N-terminal half of CheB is involved in methylesterase response to negative chemotactic stimuli in Escherichia coli. J. Bacteriol. 170: 5728-5738.

Stock, A.M., D.C. Wylie, J.M. Mottenen, A.N. Lupas, E.G. Ninfa, A.J. Ninfa, C.E. Schutt, and J.B. Stock. 1989. Phospho-proteins involved in bacterial signal transduction. Cold Spring Harbor Symp. Quant. Biol. (in press).

Taylor, R.K., M.N. Hall, and T.J. Silhavy. 1983. Isolation and characterization of mutations altering expression of the major outer membrane porin proteins using the local anesthetic procaine. J. Mol. Biol. 166: 273-282.

van Alphen, W. and B. Lugtenberg. 1977. Influence of osmolarity of the growth medium on the outer membrane protein pattern of Escherichia coli. J. Bacteriol. 131: 623-630.

Weinstock, G.M., C. apRhys, M. L. Berman, B. Hampar, D. Jackson, T.J. Silhavy, J. Weisemann, and M. Zweig. 1983. Open reading frame expression vectors: A general method for antigen production in Escherichia coli using protein fusions to $\beta$-galactosidase. Proc. Natl. Acad. Sci. 80: 44324436.

Weiss, V. and B. Magasanik. 1988. Phosphorylation of nitrogen regulator I (NR $\mathrm{N}_{\mathrm{I}}$ of Escherichia coli. Proc. Natl. Acad. Sci. 85: 8919-8923.

Wylie, D., A. Stock, C. Wong, and J. Stock. 1988. Sensory transduction in bacterial chemotaxis involves phosphotransfer between Che proteins. Biochem. Biophys. Res. Commun. 151: 891-896. 


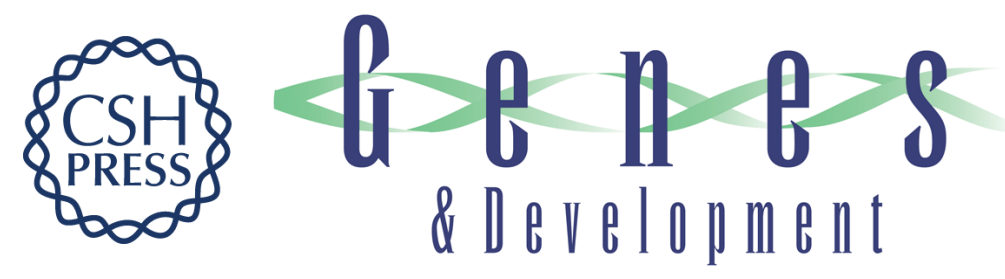

\section{A bacterial environmental sensor that functions as a protein kinase and stimulates transcriptional activation.}

M M Igo, A J Ninfa and T J Silhavy

Genes Dev. 1989, 3:

Access the most recent version at doi:10.1101/gad.3.5.598

References This article cites 29 articles, 20 of which can be accessed free at: http://genesdev.cshlp.org/content/3/5/598.full.html\#ref-list-1

License

Email Alerting

Receive free email alerts when new articles cite this article - sign up in the box at the top Service right corner of the article or click here.

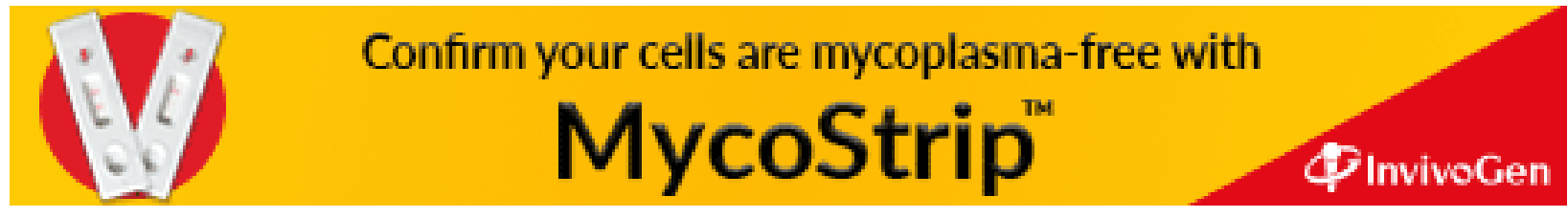

